\title{
PENGARUH PEMBERIAN BOLU KUKUS DAUN KATUK TERHADAP PRODUKSI ASI DI WILAYAH KERJA RUMAH SAKIT GRANDMED LUBUK PAKAM
}

Raini Panjaitan ${ }^{1}$, Reno Irwanto ${ }^{2}$, Nadia Husna ${ }^{3}$, Andreais Boffil Cholilullah ${ }^{4}$

Program Studi Gizi Fakultas Kesehatan Masyarakat

Institut Kesehatan Medistra Lubuk Pakam

Jl. Sudirman No. 38 Lubuk Pakam Kec. Lubuk Pakam Kab. Deli Serdang, Sumatera Utara

e-mail : raini0938p@gmail.com

DOI : https://doi.org/10.35451/jkg.v3i1.525

\begin{abstract}
Katuk leaves can increase breast milk production because it's have polyhenols and steroids were instrumental in prolactin reflex to produce breast milk, and can stimulate the hormone oxytocin to stimulate spending and flow of breast milk. Breast milk production and expenditure is influenced by two hormones, prolactin and oxytocin. This studi aims to determine the effect of giving katuk leaves steamed sponge cake for breast milk production in Grandmed Hospital Lubuk Pakam. This research method is quasi experiment with pre and posttest design. The population in this study is breastfeeding mothers of infants 0-6 months in Grandmed Hospital Lubuk Pakam. The sample is 30 people consisting of 15 control and 15 treatment group. In the treatment group was given intervention katuk leaves steamed sponge cake as much as 100 grams (2pieces) every day for 30 days. From the result of this research average frequency of breastfeeding in the control group as 8.07 time and the treatment group times as much as 10.40. While the average duration of breastfeeding in the control group as much as 6.80 minutes and 9.74 minutes in the treatment group. The result of the analysis with $T$-test was obtained $p$ Value 0,000, it can concluded that there is the effect of giving katuk leaves steamed sponge cake katuk for breast milk production.
\end{abstract}

Keywords: Steamed sponge cake katuk leaves, breast milk 


\section{PENDAHULUAN}

Periode emas atau golden period anak adalah saat 1000 hari pertama kehidupannya, yaitu dimulai pada periode dalam kandungan selama 280 hari sampai anak lahir dan mencapai usia 24 bulan. Menurut (WHO, 2011), menyatakan bahwa sebaiknya bayi yang baru lahir diberikan Air Susu Ibu (ASI) eksklusif selama 6 bulan, kemudian dilanjutkan hingga anak berusia 2 tahun. Berdasarkan data (Riskesdas, 2018), menunjukkan bahwa pola pemberian ASI pada bayi umur 0-5 bulan di Indonesia sebanyak 37,3\% ASI eksklusif, 9,3\% ASI parsial, dan $3,3 \%$ ASI predominan (menyusui bayi namun pernah memberikan sedikit air atau minuman berbasis air sebelum ASI keluar). Banyak hal yang dapat mempengaruhi produksi ASI. Produksi dan pengeluaran ASI dipengaruhi oleh dua hormon, yaitu prolaktin dan oksitosin. Prolaktin mempengaruhi jumlah produksi ASI, sedangkan Oksitosin mempengaruhi proses pengeluaran ASI. Prolaktin berkaitan dengan gizi ibu, semakin baik asupan gizinya maka produksi ASI yang dihasilkan juga semakin banyak (Mutiara dkk, 2012). Masalah yang timbul pada ibu menyusui adalah produksi ASI yang tidak maksimal. Penyebab masalah tersebut adalah asupan gizi yang rendah sehingga banyak bayi dan kebutuhan gizinya kurang terpenuhi, hal ini dikarenakan ibu tidak dapat memberikan ASI maksimal yang sesuai dengan kebutuhan nutrisi bayi (Triananinsi dkk, 2020). Berdasarkan pandangan terhadap pemberian ASI kepada bayi akan timbul upaya yang dilakukan oleh ibu, untuk meningkatkan produksi ASI. Salah satu upaya yang dilakukan adalah dengan mengkonsumsi daun katuk, dalam bentuk produk bolu kukus. Daun katuk dapat meningkatkan produksi ASI yang mengandung polifenol dan steroid yang berperan dalam reflex prolaktin untuk memproduksi ASI, serta dapat merangsang hormon oksitosin untuk memacu pengeluaran dan pengaliran ASI (Triananinsi dkk, 2020). Berdasarkan hasil observasi yang dilakukan di Rumah Sakit Grandmed Lubuk Pakam bahwa diperoleh data dari 58 ibu yang menyusui diperoleh hanya 30 ibu yang memberikan ASI ekslusif, hal ini disebabkan karena banyaknya ibu yang tidak memahami tentang menyusui, banyak ibu yang menjadi wanita karir dan kurangnya produksi ASI sehingga ibu tidak menyusui Penelitian ini bertujuan untuk meningkatkan produksi ASI dengan mengukur frekuensi menyusui selama 24 jam dan lama menyusui setiap kali ibu menyusui bayi.

\section{METODE PENELITIAN}

Jenis penelitian yang digunakan pada penelitian ini yaitu jenis penelitian 
kuantitatif dengan desain penelitian yaitu Quasi eksperimen dengan rancangan pre dan post test desain. Untuk mengetahui perbedaan produksi ASI sebelum dan sesudah dilakukan intervensi pada ibu menyusui. Pada penelitian ini menggunakan 2 kelompok kelas, yaitu kelompok intervensi (perlakuan) dan kelompok kontrol. Pada kelompok intervensi (perlakuan) diberi intervensi bolu kukus daun katuk sebanyak 100 gram (2 potong) selama 30 hari dan pada kelompok kontrol tidak diberikan intervensi. Perbedaan nilai rata-rata postest pada kelompok intervensi (perlakuan) dan kelompok kontrol dibandingkan untuk menentukan apakah terdapat perbedaan produksi ASI yang signifikan terhadap 2 kelompok tersebut. Populasi dalam penelitian ini adalah seluruh ibu menyusui bayi 0-6 bulan di wilayah kerja Rumah Sakit Grandmed Lubuk Pakam yang berjumlah 30 orang. Uji statistik yang digunakan pada penelitian ini adalah paired sampel $T$ Test, apabila $p$ value $\leq 0.05$ maka ada pengaruh pemberian bolu kukus daun katuk terhadap produksi ASI di Rumah Sakit Grandmed Lubuk Pakam.

\section{HASIL}

Tabel 1. Distribusi Karakteristik Responden Berdasarkan Usia Ibu, Pendidikan Ibu, dan Pekerjaan Ibu di Rumah Sakit Grandmed

\begin{tabular}{llll}
\hline No & Karakteristik & f & $\%$ \\
\hline
\end{tabular}

\section{Usia Ibu}

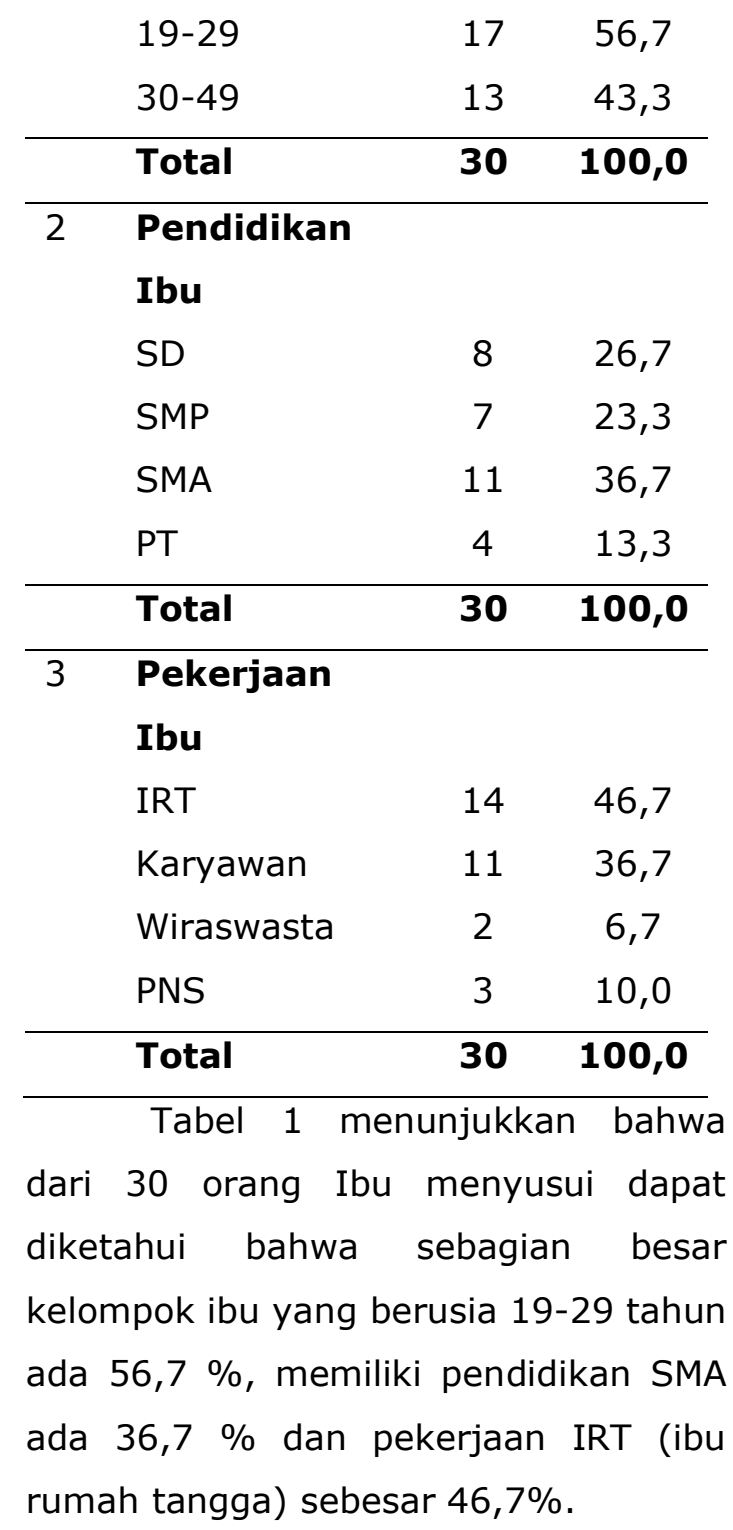

Tabel 2. Pengaruh Pemberian Bolu Kukus Daun Katuk Terhadap Frekuensi Menyusui

\begin{tabular}{lccc}
\hline Variabel & $\begin{array}{c}\text { Rata- } \\
\text { rata }\end{array}$ & $\begin{array}{c}\text { Std. } \\
\text { Deviasi }\end{array}$ & $\begin{array}{c}\text { P } \\
\text { Value }\end{array}$ \\
\hline $\begin{array}{l}\text { Frekuensi } \\
\text { Menyusui } \\
\text { (Kontrol) }\end{array}$ & 8,07 & 0,884 & \\
$\begin{array}{l}\text { Frekuensi } \\
\text { Menyusui } \\
\text { (Perlakuan) }\end{array}$ & 10,40 & 1,298 & 0,000 \\
\hline \multicolumn{1}{c}{ Tabel } & 2 & & \\
berdasarkan & hasil analisis diperoleh
\end{tabular}


adanya perbedaan frekuensi menyusui antara kontrol dengan yang diberi perlakuan dengan hasil uji statistik diperoleh $p=0,000$

Tabel 3. Pengaruh Pemberian Bolu Kukus Daun Katuk Terhadap Lama Menyusui

\begin{tabular}{lccc}
\hline Variabel & $\begin{array}{c}\text { Rata- } \\
\text { rata }\end{array}$ & $\begin{array}{c}\text { Std. } \\
\text { Deviasi }\end{array}$ & $\begin{array}{c}\text { P } \\
\text { Value }\end{array}$ \\
\hline $\begin{array}{l}\text { Lama } \\
\text { Menyusui } \\
\text { (Kontrol) }\end{array}$ & 6,80 & 1,539 & \\
$\begin{array}{l}\text { Lama } \\
\text { Menyusui } \\
\text { (Perlakuan) }\end{array}$ & 9,74 & 1,265 & 0,000 \\
\hline
\end{tabular}

Tabel 3 menjelaskan bahwa berdasarkan hasil analisis diperoleh adanya perbedaan lama menyusui antara kontrol dan yang diberi perlakuan dengan hasil uji statistik diperoleh $p=0,000$.

\section{PEMBAHASAN}

Berdasarkan hasil yang didapat peneliti diketahui bahwa pengaruh pemberian bolu kukus daun katuk terhadap frekuensi menyusui rata-rata kelompok kontrol adalah 8,07 kali dalam 24 jam sedangkan kelompok perlakuan 10,40 kali dalam 24 jam (Tabel 2). Pemberian bolu kukus daun katuk dapat meningkatkan frekuensi menyusui pada Ibu.

Tabel 3 menunjukkan bahwa pengaruh pemberian bolu kukus daun katuk terhadap lama menyusui setiap kali ibu menyusui bayi dengan rata- rata kelompok kontrol 6,80 menit dan kelompok perlakuan selama 9,74 menit. Pemberian bolu kukus daun katuk dapat meningkatkan lama menyusui bayi setiap kali menyusui bayi.

Berdasarkan hasil uji statistik dengan menggunakan uji paired $\mathrm{T}$ Test menunjukkan bahwa p. value $(0,000)$ $\leq a(0,05)$, yang berarti ada efek yang signifikan dari pemberian bolu kukus daun katuk terhadap produksi ASI ibu di wilayah kerja Rumah Sakit Grandmed Lubuk Pakam. Berdasarkan hasil penelitian Nindyaningrum dkk, (2014) menunjukkan bahwa ada pengaruh signifikan pada pemberian ekstrak daun katuk terhadap produksi ASI. Menurut Suwanti dan Kuswati (2016), bahwa pengaruh konsumsi ekstrak daun katuk terhadap kecukupan ASI pada ibu menyusui menunjukkan setelah mengkonsumsi ekstrak daun katuk ibu yang menyusui mengalami kenaikan produksi ASI sampai melebihi kebutuhan bayinya (70\%).

\section{KESIMPULAN}

Kesimpulan pada penelitian ini adalah:

a. Ada pengaruh pemberian bolu kukus daun katuk terhadap frekuensi menyusui dengan ratarata 10,40 kali dalam 24 Jam.

b. Ada pengaruh pemberian bolu kukus daun katuk terhadap lama 
menyusui dengan rata-rata 9,74 setiap kali ibu menyusui bayi.

\section{DAFTAR PUSTAKA}

Riset Kesehatan Dasar (Riskesdas). (2018). Laporan Nasional 2018. Jakarta: Badan Penelitian dan Pengembangan Kesehatan Depkes RI.

Mutiara, Erli, Adikahriani, Siti W. (2012). PENGEMBANGAN FORMULA BISKUIT DAUN KATUK UNTUK MENINGKATKAN PRODUKSI ASI. Penelitian Kesehatan. Universitas Negeri Medan.

Nindyaningrum RA., Rusmiyati, Purnomi. (2014). PENGARUH PEMBERIAN EKSTRAK DAUN KATUK TERHADAP PRODUKSI ASI PADA IBU POST PARTUM. JURNAL KEPERAWATAN DAN KEBIDANAN (JIKK), 1(6), 1-9.

Suwanti, E., \& Kuswati. (2016). PENGARUH KONSUMSI EKSTRAK DAUN KATUK TERHADAP KECUKUPAN ASI PADA IBU MENYUSUI DI KLATEN. JURNAL TERPADU ILMU KESEHATAN, 5(2), 110-237.

Triananinsi, N., Andryani, Y, Z, Basri, $F_{1}$ (2020). HUBUNGAN PEMBERIAN SAYUR DAUN KATUK TERHADAP KELANCARAN ASI PADA IBU MULTIPARA DI PUSKESMAS CAILE. JURNAL OF
HEALTHCARE TECHNOLOGY AND MEDICINE, 6(1), 12-20

World Health Organization (WHO). (2011). Exclusive breastfeeding for six Months best for babies everywhere.

https://www.who.int/mediacenter/ news/statements/2011/breastfeed ing 20110115/en/ 